\title{
Offshoring and the New Age Employee: Emerging Issues in Human Resource Management
}

\author{
Babita Srivastava \\ William Paterson University \\ Raza Mir \\ William Paterson University
}

As organizations continue to "offshore" their operations across national boundaries, they also reconfigure their relationship with their workforce. In this paper, we examine the impact of offshoring on the employeremployee contract, primarily through the lens of the exit-voice argument proposed by the economist Alfred Hirschman in 1970. Our contention is that offshoring reconfigures the employer-employee relationship, replacing earlier psychological contracts with an increasingly transactional character. We present a framework of new HR imperatives that confront organizations and employees in the post-offshoring age, and discuss the ethical challenges facing organizational theorists, who represent this debate in their research and the classroom.

\section{INTRODUCTION}

Large corporations continue to "offshore" jobs from well-paying Western locations to the Third World, primarily for the purposes of achieving labor-economies and savings associated with vertical disintegrations (Pla-Barber, Linares, \& Ghauri, 2019). The debate on the broader consequences of such offshoring rages on in the business press (Smith 2016), consultant publications (Hummels, Munch \& Xiang, 2016), and increasingly, journals devoted to managerial practice (Venkataraman, 2004) as well as organizational theory (Rodriguez \& Nieto 2016). At the heart of this debate lies unease about the transforming relationship between employees and organizations, another topic that has been subject to extensive research in the organizational literature (Rode, Huang \& Flynn, 2016). As organizations continue to attempt to socialize their employees into subjecthood (Louis, 1990), issues of employee-organization relations become salient. While research has indicated that employees experience both economic and social pulls toward their organizations (Arthur, 1992), theorists have often wondered which of these pulls is more compelling in the current organizational scenario. On one hand, the employee-organization relationship can be highly economic in nature, and resemble a market transaction (Williamson, 1985).

On the other hand, there exists a psychological contract between employees and organizations, one that goes way beyond market transactions (Rousseau, 1995). The framework of social exchange theory (Blau, 1964) has been used to provide a theoretical basis for this relationship, and empirical examinations of this issue have concluded that the mutuality of investment in this relationship is the greatest determinant of the strength and success of the employee-organization relationship (Moss, Sanchez \& Heisler, 2004; Tsui et. al., 1997). 
In this paper, we argue that in the current corporate landscape, the employee-organization relationship is subjected to further shifts on account of the changing profile of the workforce. Because of offshoring and corporate downsizing, today's employees often operate in an environment where their work group is comprised of a number of traditional workers employed directly by the organization as well as a number of contracted workers drawn from different organizations, put together in order to work on a specific project. The former provide the stability and organization-specific expertise while the latter provide both functional and numerical flexibility to the organization. Often, the group starts working on projects as soon as it is formed. Also, the nature and size of the group tends to be dynamic with the post-offshoring employees being added and removed as the need dictates. As a result, the "post-offshoring worker," including the worker who is attempting to enter the workforce in the next few years, encounters an atmosphere characterized by a paradoxical combination of high hopes and declining trust. In the wake of waves of corporate downsizing (Beam, 1997), most of which have been triggered not by falling productivity but more by the exigencies of the stock market (Lowe, 1998), workers are justifiably wary of their expectations from their employers. To that extent, we may hypothesize that their relationship with their employers is moving from a psychological contract model to an economic exchange model.

How do we reconcile the ambivalence of the post-offshoring workers toward their employers with their intense need to monitor their own progress? Does this attitude on the part of the post-offshoring workers constitute a fundamental shift? How can such a challenge be met by practicing managers? How can organizational theorists assist them in developing this understanding? In the rest of this paper, we address these issues in three ways. First we use insight from Albert Hirschman's theories of exit-voice to evaluate the choices made by organizations and workers, and map out some of the ways in which organizational actions can be understood by economic/organizational theory. Second, we develop and critique a framework of newer techniques being deployed by organizations to manage the post-offshoring employee. Finally, we invoke a class analytic perspective on offshoring, and end with a discussion on the role of academic ethics in the unpacking of the discourse of offshoring.

\section{Exit, Voice and Offshoring: A Crisis in the Making?}

Attitudes toward corporate offshoring are often intensely polemical, and fluctuate wildly depending upon the source of one's information. On one hand, organizations like the Center for American Progress (https://www.americanprogress.org/issues/economy/news/2014/07/30/94864/offshoring-work-is-taking-atoll-on-the-u-s-economy/)make a passionate case that offshoring is the defining political crisis of our time, costing US workers around half a million jobs in the professional services and information sector. The AFL-CIO disputes a variety of "corporate myths" that suggest among other things that the jobs being outsourced are low-end jobs, or that offshoring is indirectly good for the US economy. On the other hand, pro-corporate research by organizations such as McKinsey suggests that offshoring is a boon to US business, and that offshoring is an important source of "value creation" for the US economy (Farrell \& Agrawal 2003).

A comprehensive transnational discussion on the macroeconomic impact of offshoring both in the manufacturing and in the white-collar sector is long overdue. However, our aims in this paper are more circumscribed. In this paper, we confine our analysis to a study of the impact of offshoring on the organizational commitment of employees in the industrialized nations of the world, and the ethical challenges posed by such phenomena for academics who teach in business schools.

\section{A Framework for Managing the Post-Offshoring Employee}

Theorists studying the workforce in the new economy have outlined a paradox; post-offshoring employees demonstrate a higher commitment to their work, but a lower commitment to their organization than traditional workers (Mir, Mir \& Mosca, 2002). This observation is consistent with the theoretical assumption that expectations of organizational loyalty are positively linked to the affective commitment of workers, and that work commitment is more linked to perceptions of environmental volatility.

Clearly therefore, the challenge posed by such a scenario for the organization (and by extension, the human resource manager) is to maintain the high level of work commitment demonstrated by the post- 
offshoring employees while simultaneously raising their affective commitment. In order to achieve this task, certain radical transformations have been undertaken by human resource managers. Not only does this involve the deployment of newer techniques, but it has also entailed the abandonment of a number of traditional practices in the service of the changing employee expectations. Some of the changes made in the human resource arena have been schematically represented in Figure 1. In this paper, we have chosen to focus on three of the human resource activities: recruitment, training and retention of employees. We also outline some of the factors that post-offshoring employees perceive as being of increased importance to them in their new jobs, along with those factors which they consider of lesser importance, and those factors that are as important to them as they had been to traditional workers.

\section{Recruitment}

In the past, recruiters were known to make use of mass mailings, employment agencies and other diffuse sources to hire candidates. However, with a sharpening of employee requirements and an increased emphasis on person-organization fit, recruiting tools have become more sophisticated (Cook 1997). These tools include a greater reliance on initial screening through internet-based interfaces (Slick, 1997) as well as a greater focus on employee referral. Recruitment has also been decentralized to the departmental level, with HR only playing a supportive role in most cases, unless the recruitment involves a function-spanning executive. In a related change, compensation packages for new employees are increasingly being customized rather than remaining within bureaucratic confines.

\section{Training}

To cater to the demands and the needs of post-offshoring employees, the paradigm of centralized training programs, usually occurring at the time of entry into the organization has given way to a more flexible, on the job and customized training schedule (Marcum, 1999). Moreover, training schedules now go beyond a focus on job function, and concentrate equally on developing employee flexibility and currency with respect to future jobs. Finally, many new organizations have benefited greatly from providing on-line training materials. These materials, usually accessible from firewall-protected intranet sites, provide a variety of asynchronous training options for the self-motivated post-offshoring employee.

\section{Retention}

Retention of employees, especially sophisticated knowledge workers has always been a priority issue for organizations. However, in the post-offshoring, we find that the greatest inducements for employees to stay is a promise that the organization will be able to maintain employee currency, teach them newer skills, offer job rotation, and more experiential training (Garger, 1999). At the same time, employers are becoming increasingly philosophical about the issue of turnover, and in most cases, budgeting for it by attempting to formalize and routinize work processes so that they can be easily transmitted to new employees.

Overall, in the new corporate landscape, we find that employees continue to explore avenues where they may actualize their work commitment. To that end, new workers favor opportunities to enhance their skills, a flexible work environment, access to newer hardware and software, and the chances of job rotation and horizontal mobility. Their diminished affective commitment finds expression in a diminished emphasis on job continuity and organizational culture. They are also less likely to be geographically rooted, and are more easily persuaded to move, even to foreign locations. Ultimately, the picture of the post-offshoring employee is that of a driven and innovative worker, but one who is far less loyal to any organizational setting. Perhaps this is a mirror image of how organizations have defined their own prerogatives in the recent past. It is however important to note that much of what has been presented here as analysis really draws from experiences with relatively qualified labor. The position of unskilled labor in the postoffshoring economy has been rendered very precarious, and perhaps can only be remedied by concerted collective action to safeguard those employment benefits that were hitherto considered a matter of guarantee. This then, becomes the ultimate paradox of the post-offshoring era, where the skilled worker becomes more mobile and difficult to retain, while the unskilled worker suffers from increasing vulnerability to the rapacity of exploitation, and must necessarily resort to collective action. 


\section{The Ethical Dimension: The Role of Academics}

Two key observations need to be made about the phenomenon of offshoring. First, while offshoring has a less-than-overwhelming impact on domestic labor markets in the US and Europe, they have functioned as powerful signifiers to reduce the bargaining power of the workforce. For instance, studies show that $29 \%$ of all offshored jobs in the US in 2004 have been from unionized facilities, despite only $8 \%$ of the private workforce in the US being unionized (Bronfenbrenner \& Luce, 2004: 29). Second, it must be conceded that the terms of the discussions on the impact of offshoring have taken on a troublingly ideological character, equating the welfare of corporate actors with that of society at large. As Levy (2005: 689) suggests, in this ideological representation, "wealth transfer is equated with wealth creation, corporate interests are conflated with those of society as a whole, and the process is portrayed as natural and inevitable, leading to prosperity for industrialized and developing countries alike." If we as organizational theorists are to do better than reproduce these ideological positions as benign, we will need to work on the assumptions that undergird our arguments. Our contention is that the inability of academics at large to present the ethical dimensions of offshoring to their students represents a major lacuna in the field, which has become even more salient in the wake of disastrous crises of management behavior and corporate governance all over the world.

Of late, theorists have begun to focus on the role of business education, as an implicit accomplice of ethically bankrupt economic systems (Chikudate, 2002). The perception that the curriculum in business schools is inadequate to address these challenges (Baetz \& Sharp, 2004) has been linked to its inability to draw a distinct but definable line between the economic imperatives of profit generation and the fiduciary imperatives of ethically anchored and socially responsible behavior. The late Sumantra Ghoshal (2005), in a scathing, posthumously published analysis of business curricula contended that some of the "worst excesses of recent management practices have their roots in a set of ideas that have emerged from businessschool academics over the last 30 years." Jeffrey Pfeffer (2005) supports Ghoshal's view, and refers to a 2000 study that found the percentage of MBAs in a firm's upper echelons to be a significant mediating variable in the link between firm size and malfeasance citations. From business theorists like Henry Mintzberg (2004) and Ian Mitroff (2004) to popular publications like The Economist (2005), a significant portion of the current round of critique of business schools stems from their inability to advocate social responsibility, and to ensure that corporations earn their putative role as servants of society and allocators of social product.

This phenomenon is all too observable in the analyses of offshoring that populate much of organizational research. A survey of the literature on offshoring in the organizational field is replete with "how to" advice on what can and should be outsourced. Lesser attention is paid on issues of inequality in exchange, of the role of offshoring in the perpetration of unfair labor practices in the West as well as the Third World, and the "everyday routines of worker resistance" (Mir \& Mir, 2002) that occur on a routine basis in the post-offshoring employment landscape, routines that we as organizational theorists have been trained to dismiss as "resistance to change" and "irrational" acts. Worker responses to the some of the oppressive dimensions of the regimes of offshoring both in the West and in the Third World, often take subtle and irrational forms. Resistance to work practices often takes on a more passive, "routine" dimension (Scott, 1985).

Open confrontations are reduced, and replaced by "subtle subversions," by acts of "disengagement," and "ambiguous accommodations" (Prasad \& Prasad, 1998). For instance, instead of more confrontational practices such as work-to-rule, workers who fear that that jobs may be offshored may paradoxically feign incompetence in carefully chosen arenas, thereby subverting organizational plans for a flexible workforce (Gottfried, 1994). This response resonates with prior research observations about worker responses to largescale organizational changes such as computerization (Prasad, 1993) or re-engineering (Diplock, 1997). Workers periodically alter their level of enthusiasm for the process as a means of communicating their fears and expectations. There are also different ways in which resistance to offshoring is expressed in the recipient nations. Contrary to the dominant discourse that third world recipients of jobs from global corporations view this as manna from the heavens, the workplace in the periphery is also a contested terrain. Sometimes, rural workers in modern organizational settings may play out their resistance through the 
invocation of ghosts, spirits, legends and religious deities (Ong, 1987). They may choose to accentuate their separateness from the managerial class by refusing to accept organizational gifts, thereby ceremonially disputing the managerial posturing that there is more to the manager-worker relationship than a pact between wage and labor (Kondo, 1990). The everyday relations at the workplace on both sides of the offshoring divide are the sites of class struggle, of alienation, of the constitution of worker subjectivity, of the gendering of work and its subversion, of intra-organizational bargaining, and sometimes, of relations of

imperialism and cultural dislocation. Representing this becomes an ethical prerogative for organizational researchers who wish to exhibit true commitment to their craft.

\section{CONCLUSION}

In this paper, we have provided a theoretical framework of the commitment profile of post-offshoring workers, contending that their attitudes toward the changing corporate workplace is one of diminishing affective commitment to the organization, coupled with a paradoxically increased work commitment. Based on this contention, we have designed a model whereby HR managers may attempt to raise the affective commitment of these workers without compromising their work commitment. The model also suggests the factors that post-offshoring workers tend to emphasize more in their new work roles. Paying more attention to these factors, we suggest, may lead to HR gains with respect to recruitment and retention. Of course, this analysis does not address the broader issue of the social impact of offshoring. As we suggest in the paper, such an analysis should use economic class rather than national boundaries as the frame of reference. Often, the popular debates on offshoring gets mired in a nationalist dilemma (in particular, the popular press in the United States resorts to China-bashing as a means of presenting a critique of offshoring and its deleterious effects). The reality is that offshoring benefits corporations and elites in both the source and destination, while creating an underclass in the first world as well as the third world.

In light of these issues, perhaps it is pertinent to revisit some of our initial concerns with respect to the employee-organization relationship. We had wondered whether the dominant paradigm of the employeeorganization relationship had begun to shift from a psychological contract (Rousseau, 1995) to a model of economic exchange (Williamson, 1985). Unfortunately, much of our theoretical understanding, our survey of existing empirical research and our own empirical research on this issue points towards such a trend. In their rush to achieve immediate gains, or perhaps having their feet held to the fire of quarterly earnings by stockholders, employers are in danger of completely reconstituting their psychological contracts with employees. Such a situation, if it translates into greater HR costs, is likely to prove to be economically unsuitable in the long run.

Also, in the face of increasingly ideological representations of offshoring, organizational researchers and management academics face an important ethical task. They need to marshal their analytical tools to go beyond the hype, and uncover the class character of the dilemma, in a manner that respectfully theorizes the hesitant and inchoate voices of those who resist their exploitation by corporations, on both ends of the offshoring space.

Our own perspective on offshoring is that it needs to be viewed more through a lens of class analysis, rather than using the nation state as a frame of reference (Henwood, 2006). Offshoring presents opportunities to the elites of both the first world and the third world, while contributing to a widening of income and privilege gaps in all parts of the world. Framing the debate on offshoring as a zero-sum war between nations leads to analytical positions that border on the xenophobic ("Is Wal-Mart a Trojan horse by which China will vanquish the US economy?") and miss the broader analytical positions that could be useful ("How does one reconcile potential gains from effective supply chain management with the mistreatment of important organizational stakeholders like labor?"). Such analysis is only useful when we use innovative units of analysis, especially those of economic class (Bluestone \& Bluestone, 1992). One could argue that a nuanced debate on offshoring would offer an important key to the critical examination of the trade theories that surround that elusive term "globalization," and serve to illuminate some very troubling ideological assumptions that underpin the macroeconomic ideology of neoliberalism. 


\section{REFERENCES}

Andersen, P.H., \& Medlin, C.J. (2016). Transient commitments and dynamic business networking. Industrial Marketing Management, 58(11), 21-43.

Arthur, J.B. (1992). The link between business strategy and industrial relations systems in American steel minimills. Industrial and Labor Relations Review, 45, 488-506.

Baetz, M.C., \& Sharp, D.J. (2004). Integrating ethics content into the core business curriculum: Do core teaching materials do the job? Journal of Business Ethics, 51(1), 53-63.

Beam, H.H. (1997). Survivors: How to keep your best people on board after downsizing. The Academy of Management Executive, 11(2), 92-94.

Blau, P.M. (1964). Exchange and power in social life. New York: Wiley.

Block, F. (1990). Postindustrial possibilities: A critique of economic discourse. Berkeley: University of California Press.

Bluestone, B., \& Bluestone, I. (1992). Negotiating the future: A labor perspective on American business. New York: Basic Books.

Bronfenbrenner, K., \& Luce, S. (2004). Offshoring: The evolving profile of corporate global restructuring. Multinational Monitor, 25(12), 25-29.

Chikudate, N. (2002). Collective myopia and defective higher educations behind the scenes of ethically bankrupted economic systems: A reflexive note from a Japanese university and taking a step toward transcultural dialogues. Journal of Business Ethics, 38(3), 205-25.

Cook, M.F. (1998). Choosing the right recruitment tool. HR Focus, 74(10), 57-59.

Diplock, P.C. (1997). Organizational change schemas: An empirical investigation of how health care managers make sense of organizational change. Unpublished dissertation at the University of Massachusetts.

Dodo, M.K. (2016). My Theory on the Trump's Phenomenon. Why Donald Trump? And Why Now? Journal of Alternative Perspectives in the Social Sciences, 7(4), 20-35.

Dubin, R. (1956). Industrial workers' worlds: A study of the "central life interests" of industrial workers. Social Problems, 3, 131-142.

Feldman, D.C., Doerpinghaus, H.I., \& Turnley, W.H. (1995). Employee reactions to temporary jobs. Journal of Management Issues, 7, 127-141.

Garger, E. (1999). Holding on to high performers: A strategic approach to retention. Compensation \& Benefits Management, 15(4), 10-18.

Ghoshal, S. (2005). Bad management theories are destroying good management practices. Academy of Management Learning and Education, 4(1), 75-95.

Gottfried, H. (1994). Learning the score: The duality of control and everyday resistance in the temporaryhelp service industry. In Resistance and power in organizations, edited by J. M. Jermier, D. Knights and W. Nord (pp. 102-127). London: Routledge.

Gouldner, A.W. (1954). Patterns of industrial bureaucracy. New York: Free Press.

Greenhaus, J.H. (1971). An investigation of the role of career salience in vocational behavior. Journal of Vocational Behavior, 1, 209-216.

Griffeth, R.W., \& Hom, P.W. (1988). A comparison of different conceptualizations of perceived alternatives in turnover research. Journal of Organizational Behavior, 9, 103-111.

Hall, R. (1968). Professionalism and bureaucratization. American Sociological Review, 33, 92-104.

Hammer, M., \& Champy, J. (1993). Reengineering the corporation: A manifesto for business revolution. New York: Harper Collins.

Harrison, B., \& Bluestone, B. (1988). The great U-turn: Corporate restructuring, laissez-faire and the rise of inequality in America. New York: Basic Books.

Harrison, B. (1994). Lean and mean: The changing landscape of corporate power in the age of flexibility. New York: Basic Books.

Henwood, D. (2006). Offshoring and Class. Left Business Observer. Retrieved from http://www.leftbusinessobserver.com/Radio.html 
Hom, P.W., \& Griffeth, R.W. (1995). Employee turnover. South Western College Publishing. Hrebiniak, L.G., \& Alutto, J.A. (1972). Personal and role-related factors in the development of organizational commitment. Administrative Science Quarterly, 17, 552-572.

Hummels, D., Munch, J.R., \& Xiang, C. (2016). Offshoring and labor markets (No. w22041). National Bureau of Economic Research.

Kalleberg, A., \& Berg, I. (1987). Work and industry: Structures, markets and processes. New York: Plenum

Kondo, D.K. (1990). Crafting selves: Power, gender, and discourses of identity in a Japanese workplace. Chicago: University of Chicago Press.

Lawler, E.E., \& Hall, D. (1970). Relationship of job characteristics to job involvement, satisfaction, and intrinsic motivation. Journal of Applied Psychology, 54, 305-312.

Levy, D.L. (2005). Offshoring in the New Global Political Economy. Journal of Management Studies, $42(3), 685-693$.

Louis, M.R. (1980). Career Transitions: Variations and Commonalities. Academy of Management Review, $5,329-340$.

Lowe, K.B. (1998). Downsizing and firm performance: Panacea or paradise lost? The Academy of Management Executive, 12(4), 130-142.

Marcum, J.W. (1999). Effective Training Strategies: A Comprehensive Guide to Maximizing Learning in Organizations. National Productivity Review, 18(4), 71-76.

Mintzberg, H. (2004). Developing Managers Not MBA's: A Hard Look at the Soft Practice of Managing and Management Development. New York: FT Prentice Hall.

Mir, A. (1997). The transformation of work: A critical examination the new organizational paradigm. Unpublished doctoral dissertation, University of Massachusetts, Amherst.

Mir, A., Mosca, J., \& Mir, R. (2002). The post-offshoring employee and organizational commitment. Public Personnel Management, 31(2), 187-200.

Mir, R., \& Mir, A. (2002). The organizational imagination: From paradigm wars to praxis. Organizational Research Methods, 5(1), 105-125.

Mir, R., \& Mir, A. (2005). 'Diversity: The Cultural Logic of Global Capital?' In A.M. Konrad, P. Prasad, \& J.L. Pringle (Eds.), Handbook of Workplace Diversity (pp. 167-188). London: Sage.

Mirels, H.L., \& Garrett, J.B. (1971). The Protestant ethic as a personality variable. Journal of Consulting and Clinical Psychology, 36, 40-44.

Mitroff, I. (2004). An open letter to the deans and the faculties of American business schools. Journal of Business Ethics, 54(2), 185-190.

Moss, S., Sanchez, J., \& Heisler, W. (2004). Are Your Employees Avoiding You? Managerial Strategies for Closing the Feedback Gap. The Academy of Management Executive, 18(1), 32-40.

Mowday, R.T., Porter, L.W., \& Steers, R. (1982). Employee-organization linkages. New York: Academic Press.

Ong, A. (1987). Spirits of resistance and capitalist discipline: Factory women in Malaysia. Albany, NY: State University of New York Press.

Pfeffer, J. (2005). Why do bad management theories persist? A comment on Ghoshal. Academy of Management Learning and Education, 4(1), 96-101.

Pla-Barber, J., Linares, E., \& Ghauri, P.N. (2019). The choice of offshoring operation mode: A behavioural perspective. Journal of Business Research, 103, 570-580.

Prasad, P. (1992). Work computerization as symbol and experience: An inquiry into the meanings of technological transformation. Unpublished dissertation at the University of Massachusetts.

Reich, R. (1991). The work of nations: Preparing ourselves for 21st century capitalism. New York: Random House.

Rifkin, J. (1995). The end of work: The decline of the global labor force and the dawn of the post-market era. New York: Putnam Books. 
Rode, J.C., Huang, X., \& Flynn, B. (2016). A cross-cultural examination of the relationships among human resource management practices and organisational commitment: An institutional collectivism perspective. Human Resource Management Journal, 26(4), 471-489.

Rodriguez, A., \& Nieto, M.J. (2016). Does R\&D offshoring lead to SME growth? Different governance modes and the mediating role of innovation. Strategic Management Journal, 37(8), 1734-1753.

Rousseau, D.M. (1995). Psychological contracts in organizations. Thousand Oaks, CA: Sage Publications.

Scott, J.C. (1985). Weapons of the weak: Everyday forms of peasant resistance. New Haven: Yale University Press.

Slick, B. (1998). Sorting Through Web Recruitment Options. Internet Week, p.19.

Smith, N. (2016, October 26). Globalization Goes Into Reverse. Businessweek. Retrieved from https://www.bloomberg.com/view/articles/2016-10-26/globalization-goes-into-reverse

The Economist. (2005). Business schools: Bad for business? Retrieved January 20, 2016, from http://www.economist.com/business/displaystory.cfm?story_id=3672752

Venkatraman, N. (2004). Offshoring Without Guilt. Sloan Management Review, 45(3), 14-30. 


\section{APPENDIX}

FIGURE 1

THE OFFSHORING-DOWNSIZING RELATIONSHIP

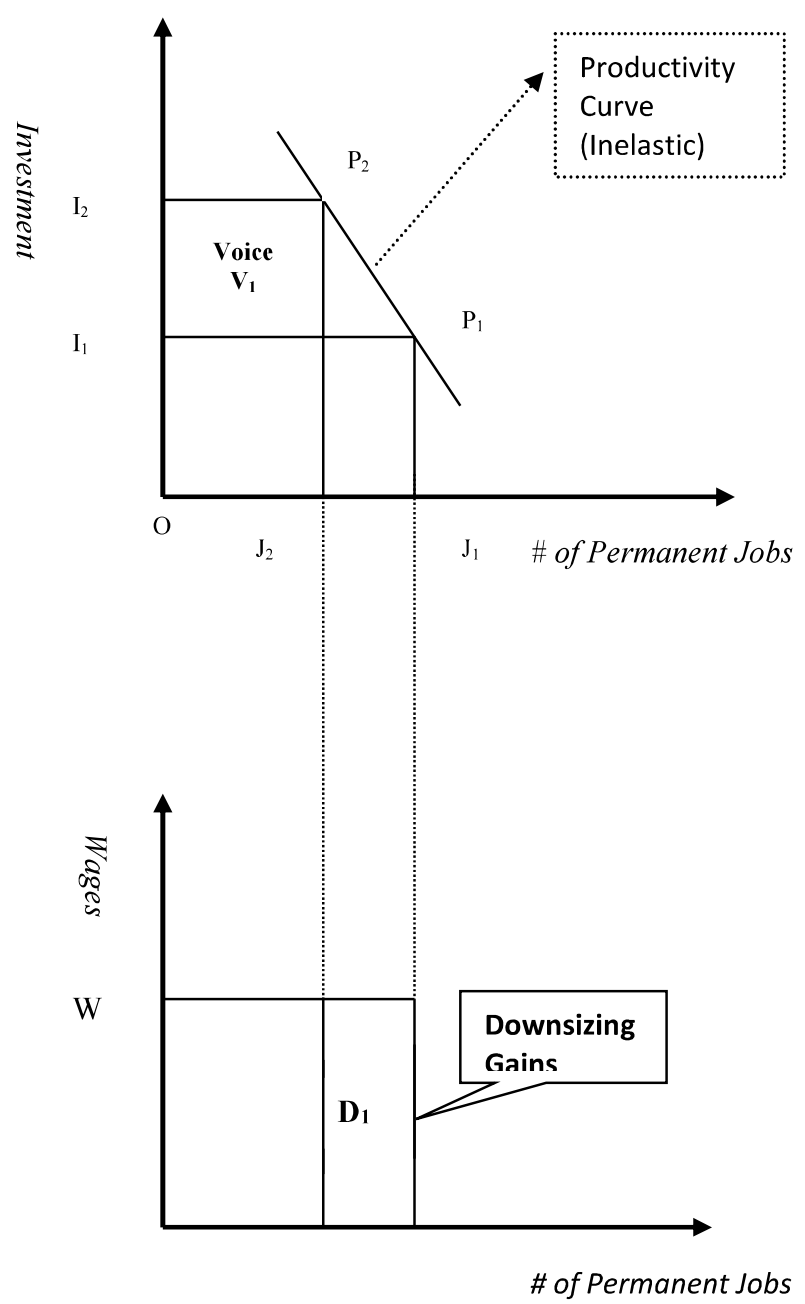

$\mathrm{I}_{2}$

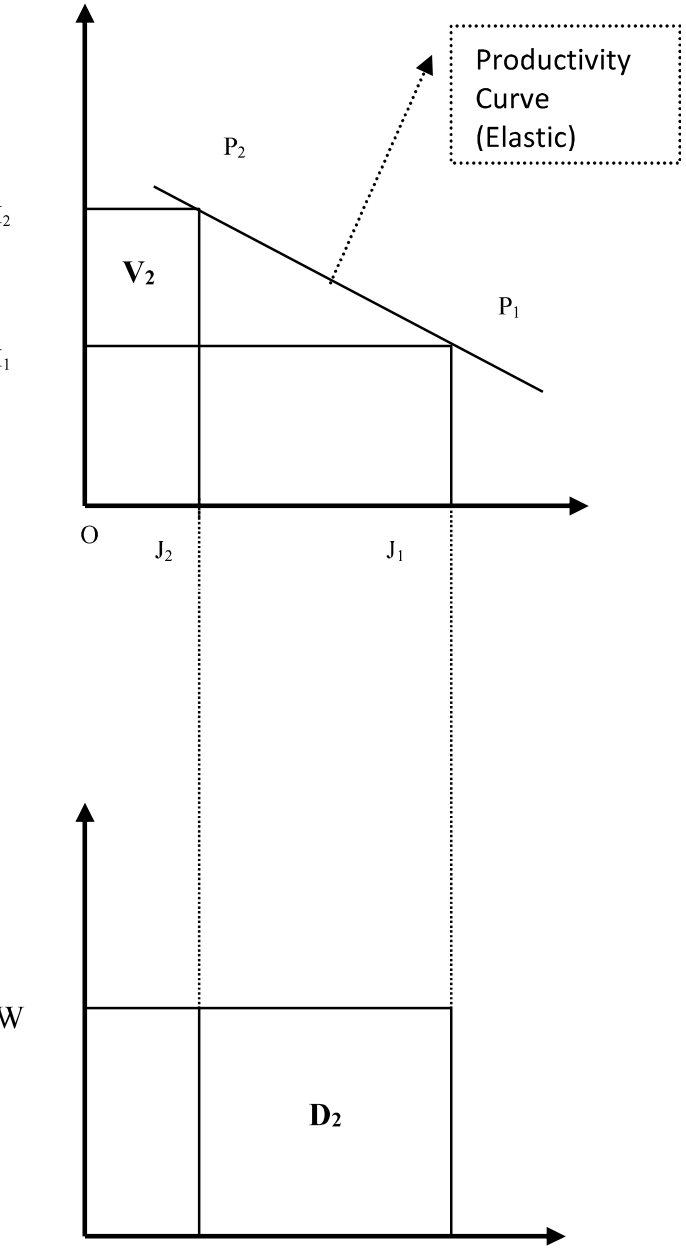

Scenario A: In an economy characterized by domestic production, the productivity curve is inelastic, and labor voice is a more powerful force.

Scenario B: As offshoring increases, the productivity curve gets more elastic. Managerial options to downsize in domestic market gain upper hand over labor voice. 
FIGURE 2

POSSIBLE TRENDS IN THE SHIFTING PRODUCTIVITY CURVE
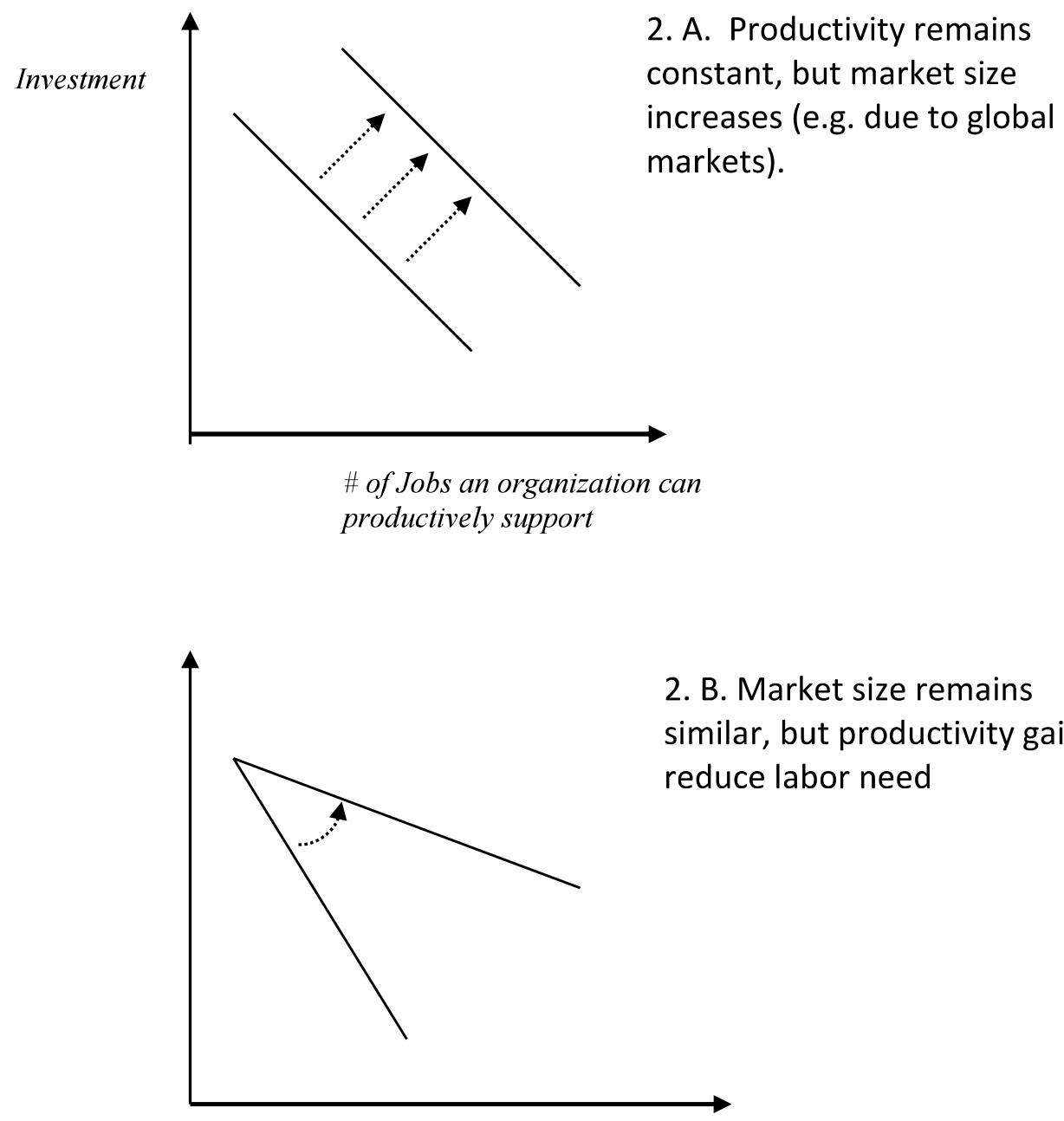

2. B. Market size remains similar, but productivity gains reduce labor need

2. C. A combination of productivity increase and market increase, augments

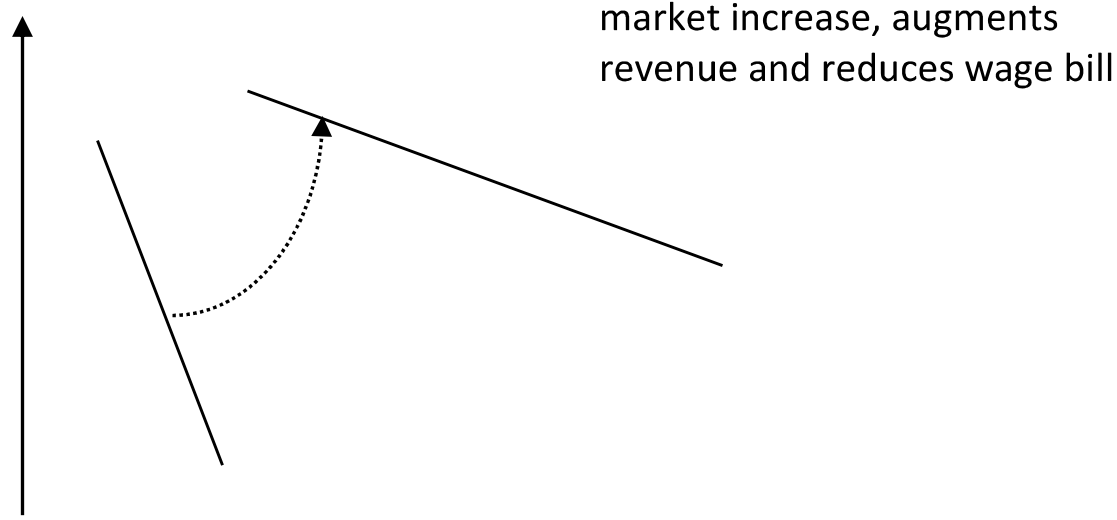


FIGURE 3

A FRAMEWORK OF HR POSSIBILITIES IN A POST-OFFSHORING WORKPLACE

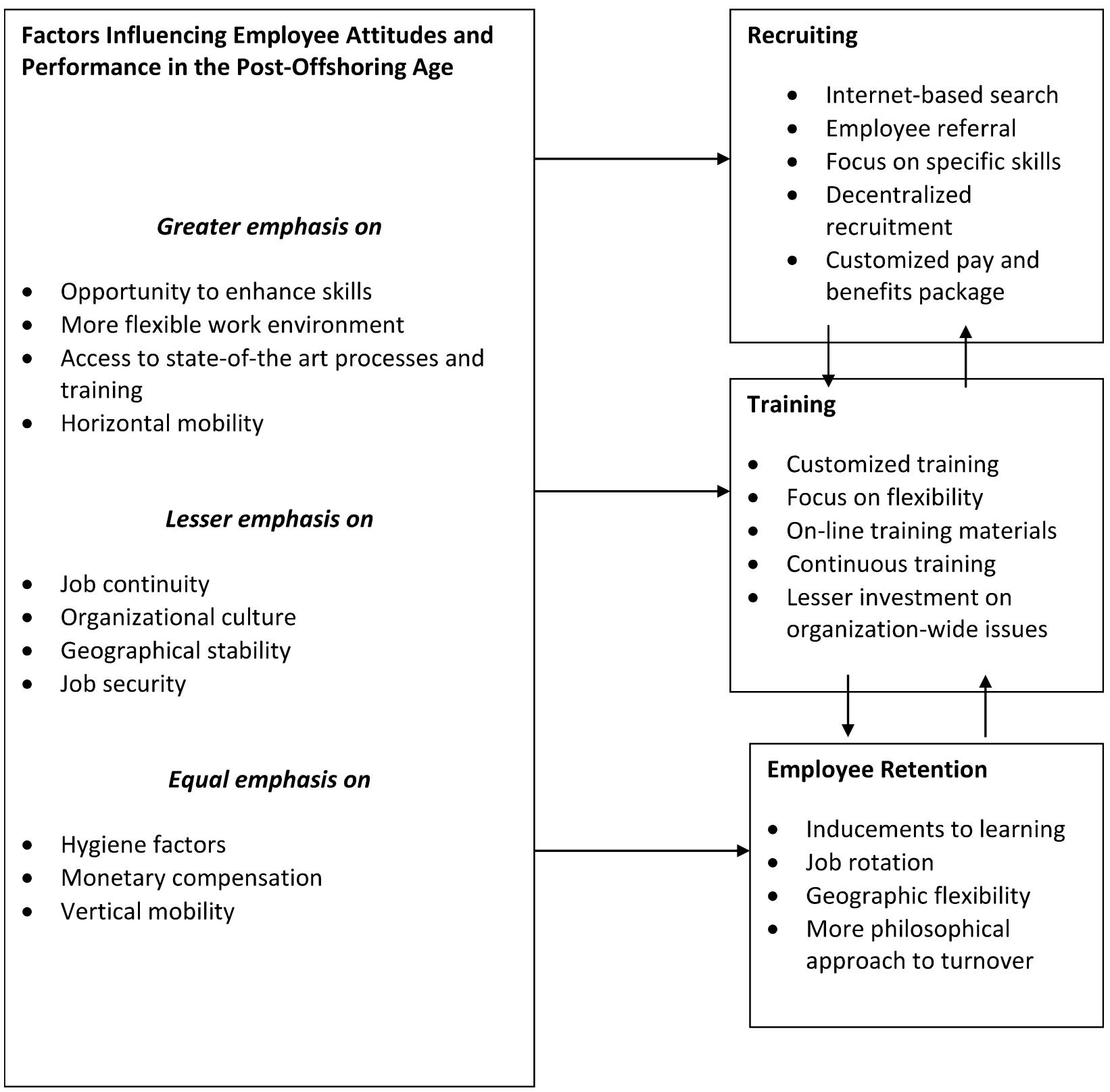

